\title{
Radiographic evaluation of dental anomalies in patients with congenital Zika virus syndrome
}

Phillipe Nogueira Barbosa ALENCAR(a)

Maria Cláudia de Freitas LIMA(a)

Isabella Fernandes CARVALHO(a)

Lavina Sousa ARAÚJO(a)

Paulo Goberlânio de Barros SILVA(a)

Luiza Lassi de Araújo LOPES(a)

José Vitor Mota LEMOS(a) (iD

Fabrício Bitú SOUSA ${ }^{(a)}$

(a) Centro Universitário Christus - Unichristus, Postgraduate Program in Dental Sciences, Christus University Center, Fortaleza, CE, Brazil.

Declaration of Interests: The authors certify that they have no commercial or associative interest that represents a conflict of interest in connection with the manuscript.

\section{Corresponding Author:}

Luiza Lassi de Araújo Lopes

E-mail: lulassi@hotmail.com

hitps://doi.org/10.1590/1807-3107bor-2021.vol35.0043

Submitted: July 8, 2020

Accepted for publication: Ocober 30, 2020

Last revision: December 10, 2020
Abstract: Numerous studies have reported abnormalities in the development of oral structures in congenital infections that also involve microcephaly. In this context, it is necessary to identify possible dental anomalies of shape and/or number in patients with Zika virus syndrome using radiography. The study population consisted of 35 children born with congenital ZIKV who underwent intraoral radiographic examinations for 24 consecutive months. A modified periapical technique was performed in an occlusal position for the maxilla and mandible. Categorical data were expressed as absolute and percentage frequencies and compared using Pearson's Chi-square test, with a 95\% confidence interval. Of the entire sample, eight children $(22.8 \%)$ had dental anomalies of shape and/or number, and four children (11.4\%) presented with both anomalies, with agenesis of the upper and lower deciduous/permanent incisors and dental form modifications, such as microdontia and anomalous cusps. When we considered age and sex, there was no statistically significant difference between patients who presented with agenesis and those who presented with modifications. Children with congenital Zika virus syndrome were more likely to have dental modifications in the number and shape of their teeth, and it is essential to implement medium- to long-term monitoring to diagnose other possible alterations throughout the development of the mixed and permanent dentition, favoring their treatment.

Keywords: Zika Virus; Microcephaly; Congenital Abnormalities.

\section{Introduction}

Zika virus (ZIKV) is an arbovirus transmitted by Aedes aegypti mosquitos, which was first reported in monkeys of the Zika Forest in Uganda in 1947. In 1952, the virus was first isolated in humans in Uganda and Tanzania. Until 2007, cases had rarely been reported in humans; therefore, ZIKV was not considered a significant public health problem. However, since then, a viral outbreak in Yap, a Micronesian Island, in 2007 and major epidemics in French Polynesia, New Caledonia, Cook Islands, and Easter Island in 2013 and 2014 have been attributed to ZIKV, which led to a change in how it's viewed. ${ }^{1,2}$

In Brazil, between late April 2015 and early 2016, there was a ZIKV epidemic that mainly occurred in the northeastern region of the country; 
it is estimated that over 1 million Brazilians were infected during this period. This event led the Brazilian Ministry of Health to declare a Public Health Emergency of national concern in November 2015, and following the emergence of new cases in other countries, in February 2016, the World Health Organization declared a Public Health Emergency of world interest. ${ }^{1,3,4}$

Six months after the onset of the ZIKV outbreak in Brazil, there was a sudden increase in newborns with microcephaly. In 2015, 1248 new suspected cases were recorded, which corresponds to a prevalence of 99.7 per 100,000 live births, representing a 20 -fold increase compared to the prevalence in recent years. On January 4, 2016, the Ministry of Health reported the birth of 3174 microcephalic babies, most of whom were in Pernambuco and almost all were in northeastern Brazil. ${ }^{1,2,5}$

In March 2019, the Ministry of Health epidemiological bulletin reported a national total of 17,041 cases of microcephaly between epidemiological weeks 45/2015 and 52/2018. Out of these cases, 3,332 cases were confirmed to be ZIKV infections, while the others remained under investigation or were discarded. In the state of Ceará, the April 2018 State Department of Health epidemiological bulletin revealed 163 confirmed cases of microcephaly suggestive of congenital ZIKV infection, while the other cases remained under investigation or were discarded. In the capital of Fortaleza, 57 cases were confirmed. ${ }^{6,7}$

The most severe neurological consequence of ZIKV infection is microcephaly, which is characterized by a reduction in normal brain volume. Other congenital ZIKV-related changes that have been reported are severe eye damage, hearing loss, lack of muscle tone, and arthrogryposis. These changes have been found even in children without microcephaly who were born in regions of Brazil where the virus was endemic. ${ }^{5,8,9}$

Although many features of this syndrome are common in other congenital infections, such as rubella, syphilis, or toxoplasmosis, there are some distinguishing features of congenital ZIKV, such as severe microcephaly with a partially collapsed skull, a thin cerebral cortex with subcortical calcifications, macular healing, focal pigmentary retinal staining, congenital contractures, and early marked hypertonia with symptoms of extrapyramidal involvement. ${ }^{10}$

In the literature, there are reports of abnormalities in the development of oral structures associated with congenital infections, such as syphilis and rubella, that also involves microcephaly; manifestations of bone, dental, and maxillary atresia, ogival palate, saddle nose, and Hutchinson's teeth (dental malformations) have been commonly reported. ${ }^{11,12}$

In this context, it is necessary to identify possible dental tissue malformations in patients with this disease to reduce the sequelae and possible future complications.

\section{Methodology}

A quantitative descriptive cross-sectional study was performed. The study population consisted of 35 children born with congenital ZIKV who were evaluated monthly by oral inspection, palpation, and clinical examination at the Unichristus School of Dentistry for 24 consecutive months. Additionally, intraoral radiographic examinations were performed every 6 months.

The Ethics Committee of the participants' educational institution approved the research, according to the protocol CEP: 60740616.4.0000.5049. This research followed the guidelines of the Helsinki Declaration and the STROBE guidelines. A free and informed consent form was read and signed by the participants' parents prior to the research.

Radiography was performed to diagnose possible dental anomalies in the number and shape of the teeth and to visualize the extent of the alveolar processes in the patients. A modified periapical technique was performed with a number 2 phosphorus plate (Express, Instrumentarum, Milwaukee, USA) in an occlusal position for the maxilla (Figure 1) and for the mandible (Figure 2) in an attempt to visualize a considerable amount of adjacent dental elements and bones within both arches. This modification helped with the examination and required only minimal cooperation from the child. The long axis of the phosphorus plate was positioned in the oral cavity of each child, perpendicular to the median sagittal plane, and was stabilized with the patient's occlusion and the help of the child's parents. 
For periapical radiographs of the upper arch, the central beam of radiation was directed towards the glabellar region with 0 -degree horizontal angulation and 65-degree vertical angulation. For the lower area, the central beam was directed to the central region of the buccal floor with a 0-degree horizontal angle and a vertical angle perpendicular to the long axis of the plate. The patients were positioned next to the guardians, wearing lead aprons, and a thyroid vest for proper examination.

The EXPRESS digital imaging card scanner (Express, Instrumentarum) was used. The exposure parameters for each radiograph were $0.25 \mathrm{~s}, 60 \mathrm{kV}$,

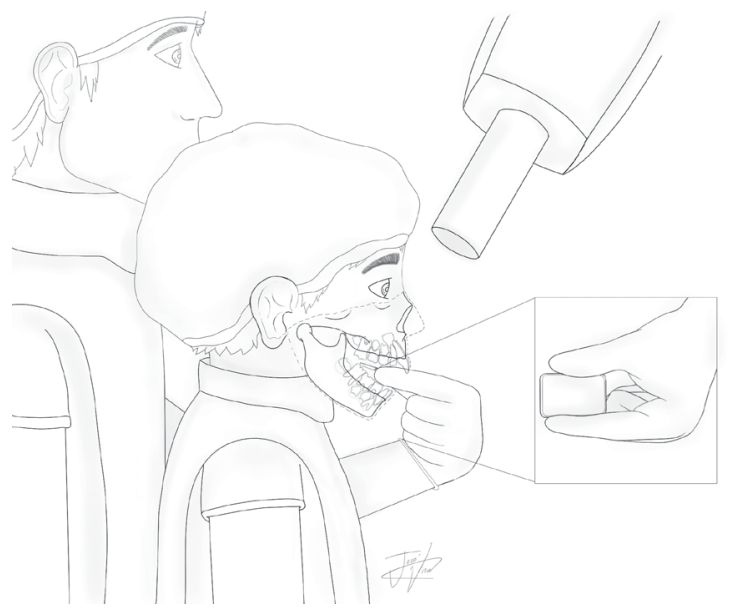

Figure 1. Representative illustration of modified periapical technique in an occlusal position for the maxilla.

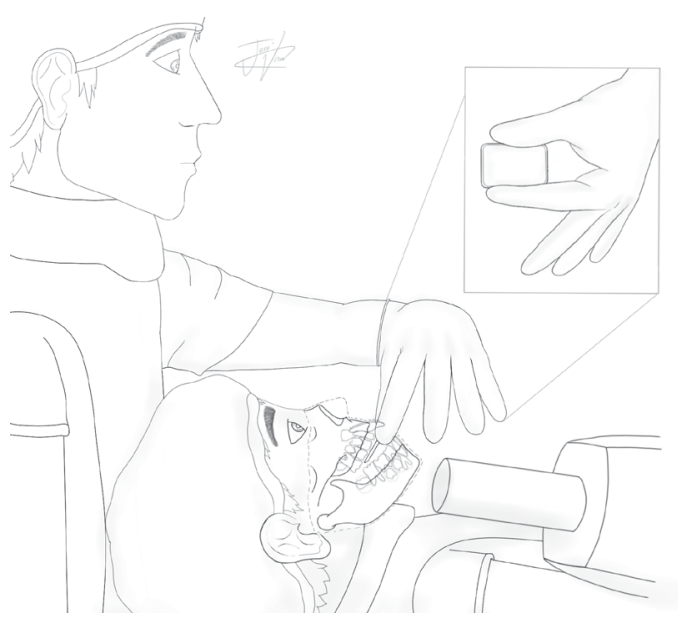

Figure 2. Representative illusttration of modified periapical technique in an occlusal position for the mandible. and $6 \mathrm{~mA}$. After image acquisition and processing, Cliniview software (Instrumentarium, Tuusula, Finland) was used for image interpretation and brightness and contrast adjustments as needed.

Table 1. List of patients and the presence of modifications found.

\begin{tabular}{|c|c|c|c|}
\hline Patient & Age in months & $\begin{array}{l}\text { Number of } \\
\text { modifications }\end{array}$ & $\begin{array}{c}\text { Shape } \\
\text { modifications }\end{array}$ \\
\hline 1 & $42 \mathrm{~m}$ & No & Yes \\
\hline 2 & $39 \mathrm{~m}$ & No & No \\
\hline 3 & $42 \mathrm{~m}$ & No & No \\
\hline 4 & $40 \mathrm{~m}$ & No & No \\
\hline 5 & $30 \mathrm{~m}$ & Yes & Yes \\
\hline 6 & $30 \mathrm{~m}$ & Yes & Yes \\
\hline 7 & $43 \mathrm{~m}$ & No & No \\
\hline 8 & $43 \mathrm{~m}$ & Yes & No \\
\hline 9 & $50 \mathrm{~m}$ & No & No \\
\hline 10 & $40 \mathrm{~m}$ & No & No \\
\hline 11 & $42 \mathrm{~m}$ & No & No \\
\hline 12 & $40 \mathrm{~m}$ & No & No \\
\hline 13 & $43 \mathrm{~m}$ & No & No \\
\hline 14 & $33 \mathrm{~m}$ & No & No \\
\hline 15 & $38 \mathrm{~m}$ & No & No \\
\hline 16 & $40 \mathrm{~m}$ & No & No \\
\hline 17 & $30 \mathrm{~m}$ & No & No \\
\hline 18 & $40 \mathrm{~m}$ & No & No \\
\hline 19 & $29 \mathrm{~m}$ & No & No \\
\hline 20 & $21 \mathrm{~m}$ & No & No \\
\hline 21 & $43 \mathrm{~m}$ & No & No \\
\hline 22 & $40 \mathrm{~m}$ & No & No \\
\hline 23 & $40 \mathrm{~m}$ & No & No \\
\hline 24 & $39 \mathrm{~m}$ & No & No \\
\hline 25 & $43 \mathrm{~m}$ & Yes & No \\
\hline 26 & $37 \mathrm{~m}$ & No & No \\
\hline 27 & $43 \mathrm{~m}$ & No & No \\
\hline 28 & $43 \mathrm{~m}$ & Yes & Yes \\
\hline 29 & $39 \mathrm{~m}$ & No & No \\
\hline 30 & $40 \mathrm{~m}$ & No & No \\
\hline 31 & $43 \mathrm{~m}$ & No & Yes \\
\hline 32 & $40 \mathrm{~m}$ & No & No \\
\hline 33 & $44 \mathrm{~m}$ & No & No \\
\hline 34 & $39 \mathrm{~m}$ & No & No \\
\hline 35 & $42 \mathrm{~m}$ & Yes & Yes \\
\hline
\end{tabular}


Categorical data were expressed as absolute and percentage frequencies and compared using a Pearson's Chi-square test. All analyses were performed using the Statistical Package for Social Sciences version 17.0 software for Windows, with a 95\% confidence interval.

\section{Results}

Among the patients evaluated, 19 (54.3\%) were male and $16(45.7 \%)$ were female. At the end of the study, 12 children (34.3\%) were less than 40 months of age, and $23(65.7 \%)$ were 40 months or older.

Out of the entire sample, eight children $(22.8 \%)$ had dental anomalies of shape and/or number, and four children (11.4\%) presented with both anomalies, with agenesis of the upper and lower deciduous/ permanent incisors and dental form modifications, such as microdontia and anomalous cusps (Tables 1 and 2) (Figures 3 and 4).

When we considered age and sex, there was no statistically significant difference between patients who presented with agenesis and those who presented with modifications.

\section{Discussion}

Out of the entire sample, a total of eight children $(22.8 \%)$, after radiographic evaluations, showed some change in the shape and/or the number of teeth; half of the sample showed a change in terms of the number and shape modification. Among the alterations we found, agenesis of the lower and upper deciduous/permanent incisors was observed in approximately one-fifth of the patients $(n=6$, $17.1 \%)$. This incidence rate is higher than those observed in populations without local systemic or bone involvement, where the prevalence rate of dental agenesis in primary dentition varies between $0.2 \%$ and $2.3 \%$, affecting mainly lateral incisors ${ }^{13-16}$. These findings also disagree with those of a study by Coutinho et al. ${ }^{17}$ where they found a prevalence of $2.7 \%$ of anomalies $(n=9)$ in children without systemic involvement at an early age.

The high prevalence of changes in the number and/or shape of dental elements found in the present study are similar to that of other studies that studied pathologies, such as syphilis. Such studies often evaluated tooth shape and size anomalies

Table 2. Evaluation of the presence of agenesis and shape modifications in children with congenital Zika virus syndrome.

\begin{tabular}{|c|c|c|c|c|c|c|c|}
\hline \multirow{2}{*}{ Variables } & \multirow{2}{*}{ Total } & \multicolumn{3}{|c|}{ Agenesis } & \multicolumn{3}{|c|}{ Shape modification } \\
\hline & & No & Yes & $p$-value & No & Yes & $\mathrm{p}$-value \\
\hline \multicolumn{8}{|l|}{ Sex } \\
\hline \multirow{2}{*}{ Female } & 16 & 15 & 1 & 0.187 & 14 & 2 & 0.504 \\
\hline & $45.7 \%$ & $51.7 \%$ & $16.7 \%$ & & $48.3 \%$ & $33.3 \%$ & \\
\hline \multirow{2}{*}{ Male } & 19 & 14 & 5 & & 15 & 4 & \\
\hline & $54.3 \%$ & $48.3 \%$ & $83.3 \%$ & & $51.7 \%$ & $66.7 \%$ & \\
\hline \multicolumn{8}{|l|}{ Age in months } \\
\hline \multirow{2}{*}{ Less than 40 months } & 12 & 9 & 3 & 0.391 & 9 & 3 & 0.391 \\
\hline & $34.3 \%$ & $31.0 \%$ & $50.0 \%$ & & $31.0 \%$ & $50.0 \%$ & \\
\hline \multirow{2}{*}{$>40$ months } & 23 & 20 & 3 & & 20 & 3 & \\
\hline & $65.7 \%$ & $69.0 \%$ & $50.0 \%$ & & $69.0 \%$ & $50.0 \%$ & \\
\hline \multicolumn{8}{|l|}{ Shape modification } \\
\hline \multirow{2}{*}{ No } & 29 & $27^{*}$ & 2 & 0.004 & - & - & - \\
\hline & $82.9 \%$ & $93.1 \%$ & $33.3 \%$ & & - & - & \\
\hline \multirow{2}{*}{ Yes } & 6 & 2 & $4^{*}$ & & - & - & \\
\hline & $17.1 \%$ & $6.9 \%$ & $66.7 \%$ & & - & - & \\
\hline
\end{tabular}

*p-value $<0.05$; Fisher's exact test or Pearson's chi-square $(n, \%)$. 


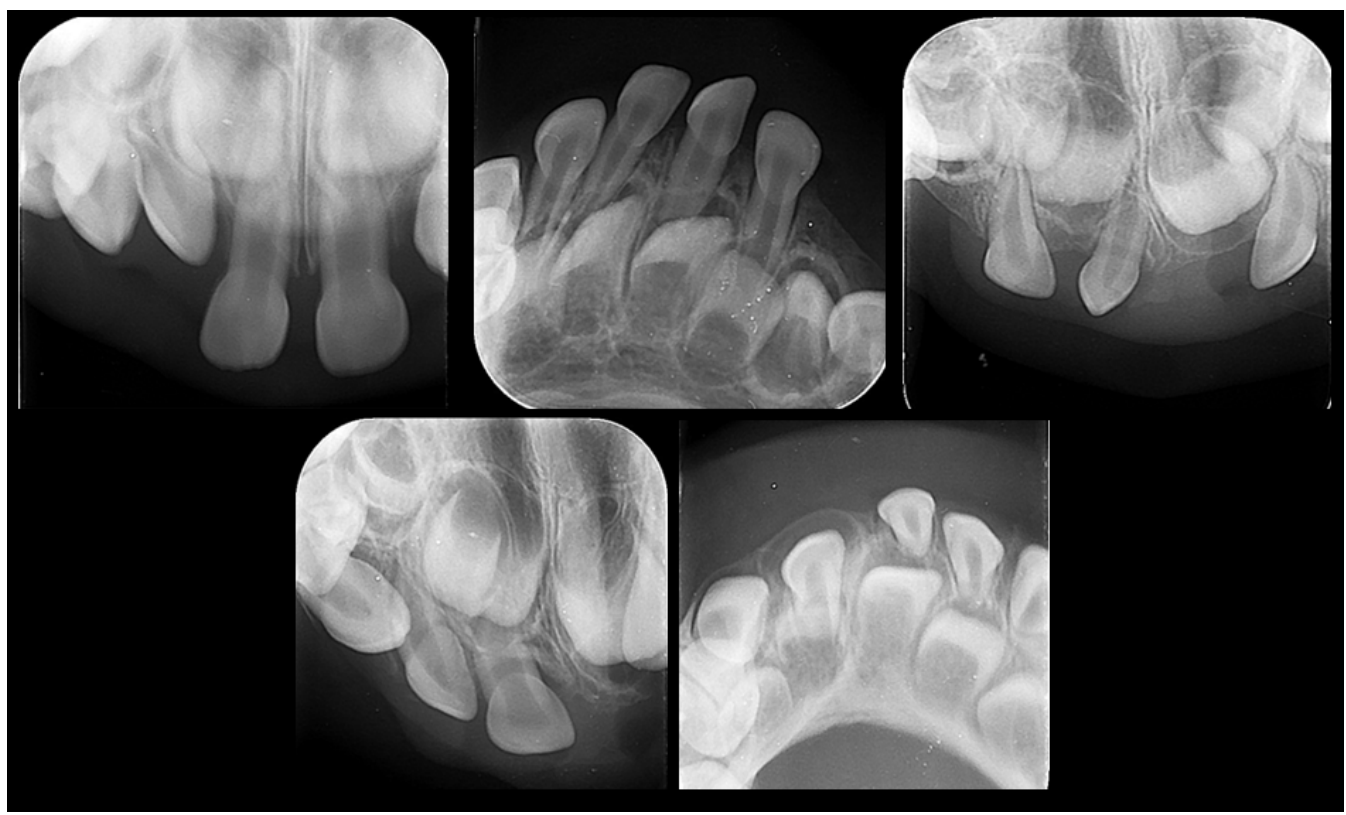

Figure 3. Dental anomalies of number.

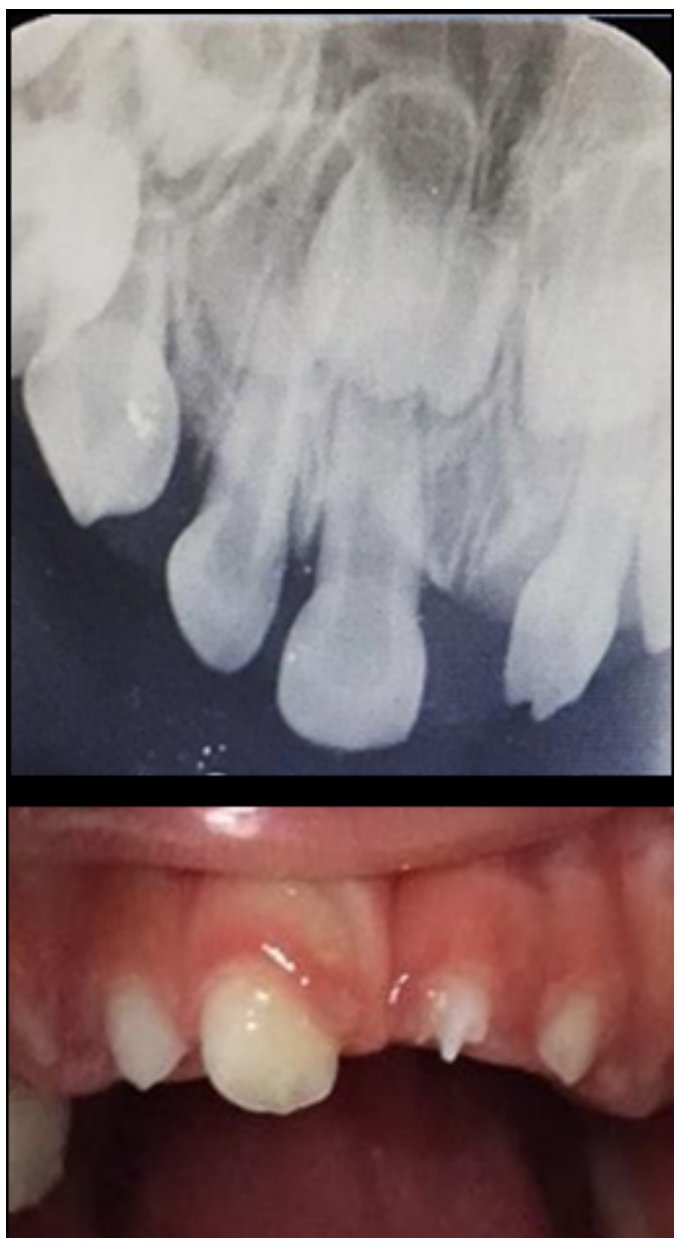

Figure 4. Dental anomalies of shape in tooth 61 . characterized by enamel and crown hypoplasia in the form of a screwdriver and/or barrel, named Hutchinson's teeth. ${ }^{18,19}$

Congenital rubella syndrome is another type of pathology that may be associated with changes similar to the ones found in the present study; in the literature, a high prevalence of dental alterations such as enamel hypoplasia, conical teeth, and screwdriver-shaped teeth have been described for this syndrome. ${ }^{20,21}$ Another factor that may explain the high rates of the number and shape anomalies found in the infants in this study is infection in embryonic cells responsible for craniofacial development. One aggravating factor is the phase of odontogenesis, which begins around the fifth intrauterine week, a period in which Zika virus infection causes significant comorbidities in the fetus..$^{22,23}$

Considering that ZIKV infects human neural progenitor cells thus resulting in a failure in the developmental mechanisms of oral and facial structures, other complications may occur later in the course of the disease ${ }^{24}$. Thus, children should be followed for medium- and long-term periods to monitor dental development during the deciduous, mixed, and permanent dentition phases. 


\section{Conclusion}

Children with congenital ZIKV syndrome were more likely to have dental modifications in the number and shape of their teeth. Thus, because of the aesthetic and functional impairments that such anomalies may cause, it is essential to implement medium-to-long-term monitoring to diagnose other possible alterations throughout the development of the mixed and permanent dentition, allowing their treatment.

\section{Acknowledgments}

We thank our institution Unichristus for providing the facilities and expertise that greatly assisted the research.

\section{References}

1. Zanluca C, Melo VC, Mosimann AL, Santos GI, Santos CN, Luz K. First report of autochthonous transmission of Zika virus in Brazil. Mem Inst Oswaldo Cruz. 2015 Jun;110(4):569-72. https://doi.org/10.1590/0074-02760150192

2. Mlakar J, Korva M, Tul N, Popović M, Polišak-Prijateli M, Mraz J, et al. Zika Virus Associated with Microcephaly. N Engl J Med. 2016 Mar;374(10):951-8. https://doi.org/10.1056/NEJMoa1600651

3. Ministério da Saúde (BR). Secretaria de Vigilância em Saúde. Departamento de Vigilância das Doenças Transmissíveis. Protocolo de vigilância e resposta à ocorrência de microcefalia relacionada à infecção pelo vírus Zika. Brasília, DF: Ministério da Saúde; 2015.

4. World Health Organization - WHO. Zika virus, Microcephaly and Guillain-Barré syndrome. Geneva: World Health Organization; 2016 [cited 2019 Apr 19]. Available from: http://www.who.int/emergencies/zika-virus/situation-report/10-march-2016/en/

5. Luz KG, Santos GI, Vieira RM. Febre pelo vírus Zika. Epidemiol Serv Saude. 2015;24(4):785-8. https://doi.org/10.5123/S1679-49742015000400021

6. Ministério da Saúde (BR). Secretaria de Vigilância em Saúde. Monitoramento integrado de alterações no crescimento e desenvolvimento relacionadas à infecção pelo vírus Zika e outras etiologias infecciosas, até a Semana Epidemiológica 52 de 2018. Brasília, DF: Ministério da saúde; 2019. [cited 2019 jun 18]. Availabe from: https://portalarquivos2.saude.gov.br/images/pdf/2019/ marco/22/2019-001.pdf

7. Ceará. Secretaria de Saúde. Síndrome congênita associada à infecção pelo vírus Zika. Boletim Epidemiológico. 30 maio 2018 [cited 2019 jan 23]. Available from: https://www.saude.ce.gov.br/wp-content/uploads/sites/9/2018/06/boletim_microcefalia_30_05_2018.pdf

8. Calvet G, Aguiar RS, Melo AS, Sampaio SA, Filippis I, Fabri A, et al. Detection and sequencing of Zika virus from amniotic fluid of fetuses with microcephaly in Brazil: a case study. Lancet Infect Dis. 2016 Jun;16(6):653-60. https://doi.org/10.1016/S1473-3099(16)00095-5

9. Sarno M, Sacramento GA, Khouri R, Rosário MS, Costa F, Archanjo G, et al. Zika virus infection and stillbirths: a case of hydrops fetalis, hydranencephaly and fetal demise. PLoS Negl Trop Dis. 2016 Feb;10(2):e0004517. https://doi.org/10.1371/journal.pntd.0004517

10. Moore CA, Staples JE, Dobyns WB, Pessoa A, Ventura CV, Fonseca EB, et al. Characterizing the pattern of anomalies in congenital Zika syndrome for pediatric clinics. JAMA Pediatr. 2017 Mar;171(3):288-95. https://doi.org/10.1001/jamapediatrics.2016.3982

11. Valente T, Scarlecio M, Israel M, Ramos ME. [Syphilis diagnosis through oral manifestations]. Rev Bras Odontol. 2008;65(2):159-64. Portuguese.

12. Moore, K.L. Embriologia clínica. 6a ed. Rio de Janeiro: Guanabara Koogan; 2000.

13. Chen YH, Cheng NC, Wang YB, Yang CY. Prevalence of congenital dental anomalies in the primary dentition in Taiwan. Pediatr Dent. 2010 Nov-Dec;32(7):525-9.

14. Kapdan A, Kustarci A, Buldur B, Arslan D, Kapdan A. Dental anomalies in the primary dentition of Turkish children. Eur J Dent. 2012 Apr;6(2):178-83. https://doi.org/10.1055/s-0039-1698948

15. Gomes RR, Fonseca JA, Paula LM, Acevedo AC, Mestrinho HD. [Dental anomalies in primary dentition and their corresponding permanent teeth]. Clin Oral Investig. 2013;2014(18):1361-7. Portuguese. https://doi.org/10.1007/s00784-013-1100-6

16. Marinelli A, Giuntini V, Franchi L, Tollaro I, Baccetti T, Defraia E. Dental anomalies in the primary dentition and their repetition in the permanent dentition: a diagnostic performance study. Odontology. 2012 Jan;100(1):22-7. https://doi.org/10.1007/s10266-011-0021-6

17. Coutinho TC, Tostes MA, Santos ME, Bastos VA. Anomalias dentárias em crianças: um estudo radiográfico. Rev Odontol Univ Sao Paulo. 1998;12(1):51-5. https://doi.org/10.1590/S0103-06631998000100009

18. Waterloo MRO, Lange AAR. [Oral aspects of congenital syphilis: case report]. Rev Ibero-am Odontopediatr Odonto Bebê. 2004;7(36):132-37. Portuguese.

19. Leão JC, Gueiros LA, Porter SR. Oral manifestations of syphilis. Clinics (São Paulo). 2006 Apr;61 (2):161-6. https://doi.org/10.1590/S1807-59322006000200012 
20. Bhatia SK, Goyal A, Dubey M, Kapur A, Ritwik P. Congenital Rubella Syndrome: dental manifestations and management in a 5 year old child. J Clin Pediatr Dent. 2012;37(1):71-5. https://doi.org/10.17796/icpd.37.1.m8281502231550u2

21. Hall RK. Prevalence of developmental defects of tooth enamel (DDE) in a pediatric hospital department of dentistry population (1). Adv Dent Res. 1989 Sep;3(2):114-9. https://doi.org/10.1177/08959374890030020801

22. Vaysse F, Bah A, Kemoun P, Cousty S. Biologie du développement dentaire. Arch Ped. 2015;22(5 Suppl 1):149-50.. https://doi.org/10.1016/S0929-693X(15)30074-9.

23. Xavier-Neto J, Carvalho M, Pascoalino BS, Cardoso AC, Costa AM, Pereira AH, et al. Hidrocefalia e artrogripose em modelo imunocompetente de rato com teratogenia ZIKA: um estudo de desenvolvimento. PLoS Negl Trop Dis. 2017;11(2):e0005363. https://doi.org/10.1371/journal.pntd.0005363

24. Cobourne MT, Sharpe PT. Tooth and jaw: molecular mechanisms of patterning in the first branchial arch. Arch Oral Biol. 2003 Jan;48(1):1-14. https://doi.org/10.1016/S0003-9969(02)00208-X 